\title{
The role of organic acids in heavy metal tolerance in plants
}

\author{
Natalia Osmolovskaya, Vu Viet Dung, and Ludmila Kuchaeva \\ Department of Plant Physiology and Biochemistry, Faculty of Biology, Saint Petersburg State \\ University, Universitetskaya nab., 7-9, Saint Petersburg, 199034, Russian Federation \\ Correspondence and requests for materials should be addressed to Natalia Osmolovskaya, \\ natalia_osm@mail.ru
}

\begin{abstract}
Organic acid metabolism is of fundamental importance at the cellular and at the whole plant level. In recent years there has been increased attention in the role of organic acids in modulating adaptation to the environment, including organic acids participation in the detoxification of heavy metals. The basis of the phenomenon is the ability of acids such as citrate, malate, oxalate, malonate, aconitate and tartrate to form strong bonds with heavy metal ions through metal chelatation with carboxyl groups carrying the function of donor oxygen in metal-ligands. This review deals with aspects of extracellular and intracellular chelation of heavy metal ions with the involvement of organic acids. We consider the role of metal-induced secretion of malate, citrate and oxalate by roots of various plant species in extracellular complexation of heavy metals and in the reduction of their bioavailability for plants. We also review the possible mechanisms of stimulation of metals uptake by plants under the influence of exogenous application of organic acids in the soil. The efficiency of intracellular chelation of heavy metal ions with the participation of organic acids is considered due to the importance of this strategy in hyperaccumulators and non-hyperaccumulators to improve metal tolerance in plants.
\end{abstract}

Keywords: organic acids, heavy metals, plant tolerance, organic acid secretion, chelation, malate, citrate, oxalate

Citation: Osmolovskaya, N., Dung, V. V., and Kuchaeva, L. 2018. The role of organic acids in heavy metal tolerance in plants. Bio. Comm. 63(1): 9-16. https://doi. org/10.21638/spbu03.2018.103

Author's information: Natalia Osmolovskaya, PhD, Assoc. Prof., orcid. org/0000-0001-8764-8552, Researcher ID: G-2226-2015; Vu Viet Dung, graduate student; Ludmila Kuchaeva, junior researcher, orcid.org/0000-0002-4263-9852

Manuscript Editor: Farida Minibayeva, Kazan Institute of Biochemistry and Biophysics, Kazan, Russia;

Guest Editor: Maria Shishova, Saint Petersburg State University, Saint Petersburg, Russia;

Received: December 28, 2017;

Revised: March 19, 2018;

Accepted: April 24, 2018;

Copyright: (c) 2018 Osmolovskaya et al. This is an open-access article distributed under the terms of the License Agreement with Saint Petersburg State University, which permits to the authors an unrestricted distribution and self-archiving free of charge.

Funding: No funding information have been provided.

Competing interests: The authors have declared that no competing interests exist.

\section{Introduction}

Environmental pollution by heavy metals and its negative effect on living organisms, including plants, is one of the urgent problems of our time. High concentrations of heavy metals affect the growth, development and yield of plants and can have a damaging effect on physiological and biochemical processes like photosynthesis, respiration, water relations, transport of organic substances, and mineral nutrition (Titov, Kaznina, and Talanova, 2014). However, the ability of plants to grow under heavy metal pollution indicates the existence of different mechanisms of their metal resistance (Yang, Feng, He, and Stoffella, 2005; Titov, Kaznina, and Talanova, 2014) that correspond to the two main strategies of plant survival under stress -1) the strategy of avoidance or limitation of metals uptake by plant cells and 2) the strategy of resistance (tolerance) coupled with intracellular mechanisms of metal detoxification (Chirkova, 2002; Titov, Kaznina, and Talanova, 2014). In the first case, the main role belongs to the cation-exchange properties of cell walls due to the presence of significant amounts of pectins, especially polygalacturonic and uronic acids, as pectin carboxyl groups take part in the binding of heavy metal ions, thus preventing their influx into the root cells (Meychik, Nikolaeva, Komarynets, and Ermakov, 2011). The second strategy involves the neutralization of toxic ions by various chelators and the compartmentation of free ions and complexes into vacuoles (Hall, 2002). In recent years, however, there is growing evidence for possible limitations of the influx of metal ions in plants 
due to mechanisms of their exogenous binding through the participation of several low molecular weight compounds, secreted by roots, among which significant attention is given to organic acids (Lopez-Bucio, NietoJacobo, Ramirez-Rodriguez, and Herrera-Estrella, 2000; Kochian, Pineros, Liu, and Magalhaes, 2015).

Organic acids are important metabolites formed in plants mainly in the Krebs cycle and glyoxylate cycle, as well as in the processes of $\mathrm{C}_{4}$ and CAM photosynthesis (Lopez-Bucio, Nieto-Jacobo, Ramirez-Rodriguez, ad Herrera-Estrella, 2000; Igamberdiev and Eprintsev, 2016). They can form both active cytosolic and storage vacuolar pools that can be used to maintain the ionic balance in plant cells (Osmolovskaya, Kuchaeva, and Novak, 2007). Organic acid metabolism is of fundamental importance at the cellular level for several biochemical pathways, including energy production, formation of precursors for amino-acid biosynthesis and, at the whole plant level, in modulating adaptation to the environment (Lopez-Bucio, Nieto-Jacobo, Ramirez-Rodriguez, and Herrera-Estrella, 2000). The basis of the phenomenon of metal ion detoxification with organic acids is the ability of acids such as citrate, malate, oxalate, malonate, aconitate and tartrate to form strong bonds with heavy metal ions through metal chelatation with carboxyl groups carrying the function of donor oxygen in metal-ligands (Anjum et al., 2015).

The participation of organic acids in the detoxification of heavy metals is considered in various works mainly in connection with the analysis of certain plant species' resistance to specific heavy metals. The objective of this review is to discuss advances in the study of organic acids secretion by plant roots in response to metal exposure, the role of organic acids in heavy metals uptake, and the investment of organic acids in transport and internal chelation of metals in plants.

\section{Organic acids secretion in roots and its role in metal tolerance}

The role of organic acids secretion as a possible mechanism for the enhancement of plants' tolerance to heavy metal stress was particularly intensively investigated in relation to $\mathrm{Al}$ tolerance in plants such as wheat (Delhaize, Ryan, and Randall, 1993; Ma, Ryan, and Delhaize, 2001), maize (Pellet, Grunes, and Kochian, 1995), rice (Yang et al., 2000) and buckwheat (Ma, Zheng, Matsumoto, and Hiradate, 1997). In studies on Triticum aestivum L., it was found that the main mechanism providing wheat plants resistance to the toxic effects of $\mathrm{Al}^{3+}$ ions is malate excretion by $\mathrm{Al}$-activated malate transport channels (ALMT), located in the plasma membrane of the root tip cells, which leads to the extracellular chelation of $\mathrm{Al}^{3+}$ ions and limits the flow of metals into root cells (Delhaize, Ryan, and Randall, 1993; Ma, Ryan, and
Delhaize, 2001; Ryan et al., 2011; Yang, Qi, Jiang, and Chen, 2013). The studies provided evidence that malate anions secretion is accompanied by the secretion of $\mathrm{K}^{+}$, which maintains the ionic balance and $\mathrm{pH}$ of the apoplast (Kochian, Pineros, Liu, and Magalhaes, 2015). On the other hand, it was shown that in sorghum, maize, barley, soybean and arabidopsis plants, $\mathrm{Al}$ resistance is correlated with the secretion of citrate rather than malate, which is carried out with the participation of MATE family transporters and is coupled with $\mathrm{H}^{+}$antiport (Meyer, De Angeli, Fernie, and Martinoia, 2010; Ryan et al., 2011; Wu et al., 2014). More Al-resistant genotypes of maize were shown to secrete more citrate than more sensitive ones (Pellet, Grunes, and Kochian, 1995). However, in other maize genotypes, Pineros et al. (2005) observed a weak correlation between citrate exudation and $\mathrm{Al}$ resistance, which allowed them to assume excretion of other not-yet-identified Al-chelators, for example, phenols, under exposure to $\mathrm{Al}$ stress. In rice, unlike other cereals, the MATE mechanism of $\mathrm{Al}$ resistance is less pronounced. This suggests a dominant role of $A B C$ transporters that determine efflux of UDPglucose to the cell wall. The cell wall then changes its composition and decreases Al-binding capacity. Efflux of UDP-glucose also activates the OsNrat1 transporter that moves $\mathrm{Al}^{3+}$ ions from the cell wall to the root cells; the ions are subsequently sequestered to the vacuoles, with the participation of OsALS1 transporter (Kochian, Pineros, Liu, and Magalhaes, 2015). It is suggested that plants' tolerance to $\mathrm{Al}$ stress may be achieved by parallel operation of 2 mechanisms - extracellular chelation of Al by organic acid ligands and intracellular sequester in the vacuoles of root cells (Ryan et al., 2011).

The molecular mechanism of constitutive and Alinduced ALMT and MATE gene expression is only now beginning to emerge, based on the identification of ciselements and trans-factors involved in the expression of a number of Al-resistant genes. Evidence obtained indicates that in plants of wheat and Arabidopsis, the mechanisms of both malate and citrate excretion are operational (Lopez-Bucio, Nieto-Jacobo, Ramirez-Rodriguez, and Herrera-Estrella, 2000; Kochian, Pineros, Liu, and Magalhaes, 2015). The exudation of organic acids in aluminum-tolerant plants could represent an evolutive convergence directed to cope with $\mathrm{Al}$, because organic acids effectively protect the root from $\mathrm{Al}$ toxicity. Alternatively, it may be part of a more general adaptive mechanism to increase the capability of native species to survive in acid soils, but the validity of this hypothesis remains to be investigated (Lopez-Bucio, Nieto-Jacobo, Ramirez-Rodriguez, and Herrera-Estrella, 2000). Attempts to establish whether the gene expression of enzymes involved in the synthesis of organic acids or the activity of transporters on the plasma membrane is the limiting step in the excretion of organic acids under $\mathrm{Al}$ 
stress have given conflicting results. According to the data given in several papers, in some experiments under Al stress, the effect of increasing citrate and malate synthesis and their secretion was observed along with overexpression of genes of citrate synthase, malate dehydrogenase, FEP carboxylase and other enzymes involved in the TCA cycle; however, in other cases this effect was absent (Delhaize, Gruber, and Ryan, 2007; Ryan et al., 2011; Yang et al., 2012). However, the increase in organic anions secretion was not proportional to their concentrations in roots, which suggests that the main role is played by the activity of transporters (Yang et al., 2012). It was found that the overexpression of genes encoding proteins of acids transporters on the plasma membrane led to a significant increase in $\mathrm{Al}$ resistance, i.e., $\mathrm{Al}$ acts primarily on the expression of ALMT and MATE genes (Kochian, Pineros, Liu, and Magalhaes, 2015). On the other hand, it is noted that at neutral $\mathrm{pH}$ citrate ci- $^{3-}$ as the anion of tricarbonic acid is a much stronger chelator of $\mathrm{Al}^{3+}$, as well as of $\mathrm{Fe}^{3+}, \mathrm{Zn}^{2+}$ and $\mathrm{Cd}^{2+}$, than malate ${ }^{2-}$ (Ryan, Delhaize, and Jones, 2001), whereas at acidic $\mathrm{pH}$, malate and oxalate do form more stable complexes with these metals, and at high $\mathrm{pH}$ their ability for complication is greatly reduced (Jones, 1998).

The study of the role of excretion of organic acids in plant tolerance to metals such as $\mathrm{Al}, \mathrm{Zn}, \mathrm{Cu}, \mathrm{Ni}, \mathrm{Pb}$ and $\mathrm{Cd}$ revealed that along with malate and citrate, oxalate is often found in root exudates of several plants. The secretion of oxalate by roots under $\mathrm{Al}$ stress was observed in buckwheat (Ma, Zheng, Matsumoto, and Hirade, 1997) and in a number of other species which tend to accumulate oxalate - amaranth, spinach and tomato (Ma, Zheng, Matsumoto, and Hirade, 1997; Yang, Zhang, and Zheng, 2008). On the other hand, Cd-induced secretion of oxalate was shown from the apex of tomato roots and was associated with the exclusion of $\mathrm{Cd}$ and $\mathrm{Cd}$ tolerance (Zhu et al., 2011). An inhibitor of anion channel PG blocked the secretion of oxalate, and externally added oxalate effectively eliminated Cd toxicity, preventing the entrance of $\mathrm{Cd}$ into the root, probably through the formation of the extracellular Cd-oxalate complex ( $\mathrm{Zhu}$ et al., 2011). Excretion of oxalate is also exhibited in rice plants in the presence of $\mathrm{Pb}$ (Yang et al., 2000). It is essential to note that in buckwheat and in Amaranthus hypochondriacus L., which are oxalate accumulators, no increase in secretion of oxalate (or citrate) was detected under exposure to $\mathrm{Cd}$, in contrast to that observed in the presence of $\mathrm{Al}$ (Zhu et al., 2011; Fan et al., 2016). On the other hand, when maize plants were exposed to $100 \mu \mathrm{m} \mathrm{Cu}$ or $\mathrm{Cd}$ in a hydroponic culture, significant secretion of citrate was not observed, in contrast to that observed in the presence of $\mathrm{Al}$ (Chaffai, Tekitek, and El Ferjani, 2006). It should be noted that the extracellular production of organic acids is considered an important mechanism in increasing heavy metal tolerance not only in higher terrestrial plants, but also in fungi (Sazanova et al., 2015) and in hydrophytes (Kurilenko and Osmolovskaya, 2015).

Mechanisms of metal-activated secretion of oxalate has not been well studied (Yang, Zhang, and Zheng, 2008), and a probable oxalate transporter is not yet identified. According to Yang, Zhang, and Zheng (2008), Alactivated secretion of oxalate in plants is not associated with the internal content of oxalate and, for instance, in 3-week amaranth seedlings, accumulating $55 \mu \mathrm{m}$ oxalate/g fresh biomass, oxalate secretion was 3 times lower than that in spinach, which had oxalate content of $30 \mu \mathrm{m} / \mathrm{g}$; this suggests that the principal role may belong not to oxalate synthesis de novo but to the density of anion channels in the plasma membrane. On the other hand, an important part of the effect of organic acids, including oxalate, on the absorption of metals is the solubility of the formed complex. For example, the $\mathrm{Pb}$ oxalate complex is practically insoluble, and oxalate secretion from roots can significantly reduce the bioavailability and phytotoxicity of $\mathrm{Pb}$ (Yang, Zhang, and Zheng, 2000). The Cd-oxalate complex is only partially soluble and therefore also reduces the bioavailability of $\mathrm{Cd}$ and its uptake by the root apex, particularly in the soil, where the involvement of exudates in the processes occurring in the soil is possible (Zhu et al., 2011). The phenomenon of decrease in metals uptake by plants under the impact of organic acids secretion by roots is usually attributed to the reduction in the number of ionized bioavailable forms of metals in the rhizosphere and increased competition of $\mathrm{H}^{+}$and metal ions for the adsorption sites on the cell walls of the roots (Dong et al., 2007), as well as with the formation of less bioavailable chelate complexes, which ultimately contributes to increased tolerance of plants to metals (Hall, 2002). Thus, the increased $\mathrm{Cu}$ tolerance of A.thaliana plants has been correlated with increasing levels of citrate in the root exudates, and the rise in their tolerance to $\mathrm{Pb}$-with increased levels of oxalate in root exudates (Ryan, Delhaize, and Jones, 2001).

In the experiments made on two genotypes of Chinese cabbage plants, it was shown that under $\mathrm{Zn}$ stress there was an increase in exudation of several organic acids from the roots, primarily citrate, lactate, oxalate and malate, which was higher in the more tolerant genotype (Li, Chen, and Cui, 2012). Of two species of grass from the genus Miscanthus under Cd stress, less accumulation of $\mathrm{Cd}$ in roots and shoots and more intense exudation of malate from roots were shown for the more Cd-tolerant Miscanthus sacchariflorus than for the less stable Miscanthus floridulus (Guo et al., 2017). Inhibition of the anion channel was accompanied by the blocking of malate secretion and an increase in Cd influx in M. sacchariflorus plants. Under Cd stress in M. sacchariflorus compared to M. floridulus, high up-regulation of genes of malate dehydrogenase and of malate transporter (MsALMT1) was 
observed, indicating the role of Cd-induced synthesis of malate and its secretion in the elimination of Cd toxicity by limiting the influx of $\mathrm{Cd}$ into the roots of plants.

Thus, from the works listed above, it follows that the role of organic acids excretion in plants' metal tolerance has been conceded mainly in regard to $\mathrm{Al}, \mathrm{Pb}$ and $\mathrm{Cd}$, and obviously further elaboration is needed regarding other metals.

\section{Exogenous supply of organic acids and the uptake of metals by plants.}

In recent years, along with the study of the role of organic acids excretion in enhancing the metal tolerance of plants, considerable attention has been paid to the study of the effect of exogenously added acids on the processes of metals uptake and accumulation in plants, especially in connection with the growing interest in their use as an effector in phytoremediation technologies (Turgut, Pepe, and Cutright, 2004). However, the results obtained in this area have proved to be ambiguous. Adding citrate to soil at a concentration of $3 \mathrm{mmol} / \mathrm{kg} \mathrm{did}$ not affect the uptake of $\mathrm{Cu}, \mathrm{Zn}, \mathrm{Cd}$ or $\mathrm{Pb}$ in Brassica juncea plants (Wu, Luo, Xing, and Christie, 2004), whereas at higher concentrations (10 and $20 \mathrm{mmol} / \mathrm{kg}$ ) citrate stimulated the uptake of $\mathrm{Cd}$ by 1.5 and 3 times, and $\mathrm{U}$ by 1000 times (Evangelou, Ebel, and Schaeffer, 2007). A similar dependence was observed in experiments with Nicotiana tabacum plants. The addition of citrate, oxalate or tartrate to the soil at a concentration of $5 \mathrm{mmol} /$ $\mathrm{kg}$ did not affect the supply of $\mathrm{Pb}$ to the shoot, while at a concentration of $60 \mathrm{mmol} / \mathrm{kg}$ citrate (but no other acid) doubled $\mathrm{Pb}$ content in the shoots, and at a concentration of $125 \mathrm{mmol} / \mathrm{kg}$ all the acids caused a reduction of plant biomass (Evangelou, Ebel, and Schaeffer, 2007).

Stimulation of Cd absorption after organic acids additions to the soil was also observed in rice and maize plants (Zhu et al., 2011). The increasing concentrations of citrate or oxalate in soil and sand culture caused increased uptake of $\mathrm{Cd}$ and its transport to the aerial part of tomato plants (Nigam and Srivastava, 2005). It was noted that $\mathrm{Cd}$ developed differently charged organic forms with organic acids. The concentrations of various organic forms of cadmium with organic acids in the environment correspond to the following order: organic (cation $>>$ anion $>$ neutral $)>\mathrm{Cd}^{2+}$. According to Schwab, Zhu, and Banks (2008), citrate, to a greater extent than malate or oxalate, increases the mobility and transport of $\mathrm{Cd}$ and $\mathrm{Zn}$ in the soil solution, whereas the influence of these acids on the mobility of $\mathrm{Pb}$ is minimal. It should be noted that the concentrations of organic acids applied to the soil, as a rule, significantly exceed the concentrations of acids found in the soil as a result of their natural secretion by plants (Jones, 1998). The use of lower concentrations of organic acids had a stimulating effect on the uptake of metals, whereas at higher concentrations organic acids often caused phytotoxic effects (Turgut, Pepe, and Cutright, 2004)

In a water culture the simultaneous application of $\mathrm{Cd}$ and citrate in concentrations of 5 and $250 \mu \mathrm{m}$, respectively, did not affect the uptake and accumulation of $\mathrm{Cd}$ in tomato shoots. However, the pre-incubation of plants with citrate showed doubled absorption of $\mathrm{Cd}$ and a 5-8 times increase in the concentration of Cd in xylem exudate, where at least a portion of the Cd was present as a complex with citrate (Senden, Van Paassen, Van der Meer, and Wolterbeek, 1995). In a study on Brassica napus plants in water culture, it was found that citrate application at a concentration of $2.5 \mathrm{mM}$ in medium containing 10 or $50 \mu \mathrm{m} \mathrm{Cd}$ contributed to the 1.5-times increase in the accumulation of $\mathrm{Cd}$ in roots, stems, and leaves of canola (Ehsan et al., 2014). Stimulation of Cd accumulation under the effect of exogenous citrate (but not tartrate) was shown for $\mathrm{Cd} / \mathrm{Zn}$ hyperaccumulator Sedum alfredii (Lu et al., 2013) and for Spinacia oleracea plants (Degryse, Smolders, and Parker, 2006).

According to the FIAM model of metals bioavailability, the influx of metals into the root cells occurs only in the form of ions, using various transport mechanisms, including ZIP, ABC, NRAMP transporters as well as low selective cation channels (Lux, Martinka, Vaculik, and White, 2011; Titov, Kaznina, Talanova, 2014). However, some authors do not exclude the possibility of metals uptake in chelated form, with the participation of ligands carriers (Degryse, Smolders, and Parker, 2006; Lux, Martinka, Vaculik, and White, 2011) or through the apoplast in root tips where Casparian strips are not fully formed, or directly into the xylem vessels in case the integrity of membranes is disrupted after exposure to chelators (Evangelou, Ebel, and Schaeffer, 2007). At the same time, it should be noted that exogenous application of organic acids is carried out directly in the form of acids, while the root secretion of acids is in the form of anions and can be accompanied by secretion of $\mathrm{K}^{+}$, so there is no strong acidification of the media (Ryan, Delhaize, and Jones, 2001; Kochian, Pineros, Liu, and Magalhaes, 2015)

Analyzing the possible mechanism of the stimulating effect of citrate and other exogenously applied acids on the bioavailability of metals in soil, the authors explain it mainly through the acidification of the environment, contributing to desorption of metals from the solid phase of the soil, the complexation of metals with anions of acids and their conversion into a more mobile, soluble chelated form (Panfili et al., 2009; Ehsan et al., 2014). The most important factor stimulating the absorption of Cd by plants, according to Panfili et al. (2009), is higher lability of the Cd chelate complex compared to $\mathrm{Cd}^{2+}$ ions, thus providing Cd concentration at the root surface. Given the large affinity of Cd to cell 
wall sites in comparison with its affinity to citrate (log K 6,17 and 4.98, respectively), the author argues that the dissociation of Cd-citrate complex in the diffuse layer or on the surface of the roots releases $\mathrm{Cd}^{2+}$ ions and leads to their adsorption by the cell wall, as indicated by the larger amount of labeled citrate adsorbed by roots in the presence of Cd (Panfili et al., 2009). Thus, exogenous application of organic acids, in contrast to their secretion by the roots, can lead to an increase, not decrease, of heavy metals uptake by plants.

\section{The involvement of organic acids in transport and internal chelation of metals in plants}

Along with the direct or indirect involvement of organic acids in the uptake of metals by plants, there is conclusive evidence of organic acids involvement in metals transport from roots to shoots (Lopez-Bucio, Nieto-Jacobo, Ramirez-Rodriguez, Herrera-Estrella, 2000), as well as in the detoxification of metals on the cellular level (Titov, Kaznina, and Talanova, 2014; Anjum et al., 2015). Heavy metal binding in cell cytosol involving organic ligands such as organic acids and their sequestration and immobilization in the vacuoles is considered one of the most important mechanisms of metal tolerance in plants (Lux, Martinka, Vaculik, and White, 2011; Titov, Kaznina, and Talanova, 2014). Citrate plays a special role in xylem transport of metals. Durrett, Gassmann, and Rogers (2007) emphasize that citrate plays a role in the chelation of $\mathrm{Fe}^{2+}$ during the transport of these ions in the xylem, while FRD3 mediates the efflux of citrate to the root vessels to maintain the transfer of iron to the shoot. Data have been presented on joint xylem transport of $\mathrm{Cd}$ and citrate for $\mathrm{Zn} / \mathrm{Cd}$ hyperaccumulator Sedum alfredii, which increases the transfer and accumulation of Cd in the leaves (Lu et al., 2013).

The efficiency of metals transfer in the xylem in the form of a complex with organic acids is attributed to the lower adsorption of uncharged or negatively charged chelated forms of metals by the negatively charged cell walls of xylem, as well as to a decrease in lateral removal of metals from the vessel, which was noted in particular for Zn and Cd (Senden, van Paassen, Van der Meer, and Wolterbeek, 1992). The role of organic acids in the intracellular detoxification of metals has been studied most intensively in heavy metal hyperaccumulators (Rauser, 1999; Küpper, Mijovilovich, Meyer-Klaucke, and Kroneck, 2004; Sun, Zhou, and Jin, 2006; Yang et al., 2006), and primarily for $\mathrm{Zn} / \mathrm{Cd}$ hyperaccumulators Thlaspi caerulescens and Arabidopsis halleri (Cosio, Martinoia, and Keller, 2004). In the leaves of T.caerulescens, $\mathrm{Zn}$ is sequestered predominantly in the vacuoles of epidermal cells, where it is coordinated mainly with malate (Tolra, Poschenrieder, and Barcelo, 1996). In A. halleri accumu- lation of $\mathrm{Zn}$ occurs mainly in the mesophyll cells (Zhao, Lombi, Breedon, and McGrath, 2000), where it is also coordinated with malate (Sarret et al., 2002) . Malate level in the leaves of hyperaccumulators does not depend on the increase of metal concentration in the environment; this indicates the constitutive high level of this acid in T.caerulescens (Tolra, Poschenrieder, and Barcelo, 1996; Wojcik, Skorzynska-Polit, and Tukiendorf, 2006) and also in A. halleri (Zhao, Lombi, Breedon, and McGrath, 2000).

The molar ratios of malate: $\mathrm{Zn}$ in T.caerulescens vary according to different authors from 4.8:72 (Tolrà, Poschenrieder, and Barcelo, 1996) to 97:23.6 (Wójcik, Skorzynska-Polit, and Tukiendorf, 2006), which is enough to maintain a $\mathrm{Zn}$-malate shuttle in accordance with the model in which $\mathrm{Zn}$ is chelated by malate to form a relatively weak complex in the cytoplasm which is transported to the vacuole, where the complex dissociates and $\mathrm{Zn}^{2+}$ binds with stronger chelators such as citrate or oxalate, and malate is re-exported to the cytosol (Chaffai, Tekitek, and El Ferjani, 2006). The molar ratio of citrate: $\mathrm{Zn}$ in the leaves of T.caerulescens reached 2.1:5.9 (Wójcik, Skorzynska-Polit, and Tukiendorf, 2006), and in leaves of A. halleri - 0.37:49.0 (Zhao, Lombi, Breedon, and McGrath, 2000). According to Salt et al. (1999), $\mathrm{Zn}$ can stimulate the synthesis of citrate in T. caerulescens; this has been linked to $21 \% \mathrm{Zn}$ in xylem juice and up to $38 \%$ of total $\mathrm{Zn}$ in the shoot (Salt et al., 1999). The role of the carboxylate groups of malate, citrate, and other acids in the binding of Zn, especially in mature leaves, has been shown in other works (Sarret et al., 2002; Küpper, Mijovilovich, Meyer-Klaucke, and Kroneck, 2004). In Al hyperaccumulator Melastoma malabathricum, it is assumed that $\mathrm{Al}$ is transported to the shoot in the form of citrate and stored in the vacuoles of leaf cells in the form of oxalate (Chaffai, Tekitek, and El Ferjani, 2006).

Less information is available about the specificity of Cd hyperaccumulation; however, there is evidence that in the $\mathrm{Zn} / \mathrm{Cd}$ hyperaccumulator Sedum alfredii, citrate is involved in $\mathrm{Zn}$ hyperaccumulation and $\mathrm{Zn}$ tolerance (Yang et al., 2006), whereas Cd in shoots is up to $85 \%$ associated with malate and only $15 \%$ with citrate (Lu et al., 2013). A positive correlation was found between citrate content and water soluble Cd content in the leaves of Cd hyperaccumulator Solanum nigrum L., which suggests that citrate is responsible for high accumulation of $\mathrm{Cd}$ in the leaves of this plant and the plants' resistance to it (Sun, Zhou, and Jin, 2006). The role of malate and citrate is also discussed in connection with Ni hyperaccumulation in several species of plants (Titov, Kaznina, and Talanova, 2014).

Studies on plants that are not metal hyperaccumulators also indicate the important role of organic acids in providing a mechanism of metal tolerance (Rauser, 1999; 
Ma, Ryan, and Delhaize, 2001). An increase in the content of malate, citrate and oxalate was shown in ryegrass shoots, maize roots and barley leaves with higher levels of nickel in the root medium (Yang, Baligar, Foster, and MArten, 1997), and exposure to $\mathrm{Pb}$ led to increased malate and oxalate content in the leaves of plants from genus Paraserianthus (Titov, Kaznina, and Talanova, 2014). The role of malate and citrate accumulation was reported for $\mathrm{Zn}$ tolerance in clones of Deschampsia caespitosa under high Zn content in the environment (Chaffai, Tekitek, El Ferjani, 2006). In cell suspension culture from tobacco leaves, citrate, malate and oxalate in concentrations of 6 , 17 and $0.5 \mathrm{mM}$ at $\mathrm{pH} 5.0$ were associated with 60,15 and $3 \%$ of the total $\mathrm{Cd}$ in vacuoles; the increase in $\mathrm{pH}$ led to an increase in the proportion of $\mathrm{Cd}$ associated with citrate, and reduced Cd complexation with malate and oxalate (Rauser, 1999). Metals such as $\mathrm{Zn}, \mathrm{Co}, \mathrm{Ni}$ and Cd exhibit a high affinity to citrate not only in A. hallerii (Zhao, Lombi, Breedon, and McGrath, 2000), but also in nonhyperaccumulating species (Anjum et al., 2015).

Along with malate and citrate, oxalate plays a specific role in the intracellular detoxification of heavy metals. The presence of Al-oxalate (1:3) complexes was shown in the roots and leaves of buckwheat (Ma, 2000); however, at high concentrations of $\mathrm{Al}$ in buckwheat leaves, $\mathrm{Al}-\mathrm{ci}$ trate complexes were also identified (Shen, Iwashita, and $\mathrm{Ma}, 2004)$. This suggests that $\mathrm{Al}$, in the form of $\mathrm{Al}$-citrate complexes, is transported to the leaves, where it can be converted into an Al-oxalate (Shen, Iwashita, and $\mathrm{Ma}$, 2004). A study of Spartina alternifloria grass suggested that oxalate may participate in the vacuole sequestration of $\mathrm{Cd}$ in roots and also in $\mathrm{Cd}$ transport to the shoots of this plant (Chai et al., 2012). On the other hand, in different plants research has shown the inclusion of some heavy metals in the form of oxalate in calcium oxalate crystals, particularly $\mathrm{Cd}$ and $\mathrm{Pb}$ in Eichhornia crassipes plants (Mazen and Maghraby, 1997). In tobacco seedlings in the presence of high concentrations of cadmium, the formation of $\mathrm{Cd}$ - and Ca-containing oxalate crystals in the leaf trichomes (in the vacuoles) was observed, which the authors attributed to the removal of $\mathrm{Cd}$ (Choi et al., 2001). However, in the leaves of Corchorus olitorius L. and Malva parviflora plants grown under $\mathrm{Cd}, \mathrm{Pb}, \mathrm{Cu}$ or $\mathrm{Zn}$ pollution, inclusions of these metals in the crystals of calcium oxalate were not revealed by an electron scanning microscope (Mazen, 2004; Faheed, Mazen, and Elmohsen, 2013), whereas $\mathrm{Al}$ additions to the nutrient medium were accompanied by $\mathrm{Al}$ inclusion in the crystals of $\mathrm{CaC}_{2} \mathrm{O}_{4}$ in leaves of Corchorus olitorius L. (Mazen, 2004).

\section{Conclusion}

For a long time, the multifunctional role of organic acids in plant life was considered primarily in connection with their participation in carbon metabolism, in- cluding $\mathrm{C}_{4}$ and CAM photosynthesis, Krebs and glyoxylate cycles, as well as in the formation of carbon precursors for the synthesis of amino acids and in maintaining ionic balance in plant cells. Less recognized is the idea of carboxylic acids' role in plant tolerance to abiotic stress, especially caused by heavy metals. This review, based on a brief analysis of studies conducted over the past 20 years, examines current achievements in the study of extra- and intracellular chelation of metal ions with the participation of organic acids anions, and provides information on molecular mechanisms for the involvement of these metabolites in the absorption, transport and immobilization of heavy metals in plants. The presented data give reason to consider the fundamental role of organic acids such as malate, citrate and oxalate in improving plant tolerance to heavy metals.

\section{References}

Anjum, N. A., Hasanuzzaman, M., Hossain, M. A., Thangavel, P., Roychoudhury, A., Gill, S.S., Rodrigo, M.A. M., Adam, V., Fujita, M., Kizek, R., Duarte, A. C., Pereir, E., and Ahmad, I. 2015. Jacks of metal/metalloid chelation trade in plants - an overview. Frontiers in Plant Science 6:192. https://doi.org/10.3389/fpls.2015.00192.

Chaffai, R., Tekitek, A., and El Ferjani, E. 2006. A comparative study on the organic acid content and exudation in maize (Zea mays L.) seedlings under conditions of copper and cadmium stress. Asian Journal of Plant Sciences 5(4):598606. https://doi.org/10.3923/ajps.2006.598.606.

Chai, M. W., Li, R. L., Shi, F. C., Liu, F. C., Pan, X., Cao, D., and Wen, X. 2012. Effects of cadmium stress on growth, metal accumulation and organic acids of Spartina alterniflora Loisel. African Journal of Biotechnology 11(22):6091-6099. https://doi.org/10.5897/AJB11.2804

Chirkova, T. V. 2002. Physiologicheskiie osnovy ustojchivosti rastenii [Physiological basis of plant tolerance]. 240 pp. Izdatelstvo Sankt-Peterburgskogo Universiteta, Saint Petersburg.

Choi, Y. E., Harada, E., Wada, M., Tsuboi, H, Morita, Y., Kusano, T., and San, H. 2001. Detoxification of cadmium in tobacco plants: formation and active excretion of crystals containing cadmium and calcium through trichomes. Planta 213(1):45-50. https://doi.org/10.1007/ s004250000487.

Cosio, C., Martinoia, E., and Keller, C. 2004. Hyperaccumulation of cadmium and zinc in Thlaspi caerulescens and Arabidopsis halleri at the leaf cellular level. Plant Physiology 134(2):716-725. https://doi.org/10.1104/pp.103.031948.

Degryse, F., Smolders, E., and Parker, D. R. 2006. Metal complexes increase uptake of $\mathrm{Zn}$ and $\mathrm{Cu}$ by plants: implications for uptake and deficiency studies in chelator buffered solutions. Plant and Soil 289(1/2):171-185. https:// doi.org/stable/24125504.

Delhaize, E., Gruber, B.D., and Ryan, P.R. 2007. The roles of organic anion permeases in aluminium resistance and mineral nutrition. FEBS Letters 581(12):2255-2262. https://doi.org/10.1016/j.febslet.2007.03.057.

Delhaize, E., Ryan, P. R., and Randall, P.J. 1993. Aluminum tolerance in wheat (Triticum aestivum L.): II. Aluminum-stimulated excretion of malic acid from root apices. Plant Physiology 103(3):695-702. https://doi.org/10.1104/pp.103.3.695.

Dong, J., Mao, W. H., Zhang, G. P., Wu, F. B., and Cai, Y. 2007. Root excretion and plant tolerance to cadmium toxici- 
ty - a review. Plant, Soil and Environment 53(5):193-200. https://doi.org/serials/j_1294836874517.

Durrett, T.P., Gassmann, W., and Rogers, E. E. 2007. The FRD3-mediated efflux of citrate into the root vasculature is necessary for efficient iron translocation. Plant Physiology 144(1):197-205. https://doi.org/10.1104/ pp.107.097162.

Ehsan, S., Ali, S., Noureen, S., Mahmood, K., Farid, M., Ishaque, W., Shakoor, M. B., and Rizwan, M. 2014. Citric acid assisted phytoremediation of cadmium by Brassica napus L. Ecotoxicology and Environmental Safety 106(7):164172. https://doi.org/10.1016/j.ecoenv.2014.03.007.

Evangelou, M. W. H., Ebel, M., and Schaeffer, A. 2007. Chelate assisted phytoextraction of heavy metals from soil: effect, mechanism, toxicity, and fate of chelating agents. Chemosphere 68(6):989-1003. https://doi.org/10.1016/j. chemosphere.2007.01.062.

Faheed, F., Mazen, A. M. A., and Elmohsen, S. 2013. Physiological and ultrastructural studies on calcium oxalate crystal formation in some plants. Turkish Journal of Botany 37:139-152. https://doi.org/10.3906/bot-1112-19.

Fan, W., Xu, J.M., Lou, H.Q., Xiao, C., Chen, W.W., and Yang, J. L. 2016. Physiological and molecular analysis of aluminium-induced organic acid anion secretion from grain amaranth (Amaranthus hypochondriacus L.) roots. International Journal of Molecular Sciences 17(5):608. https://doi.org/10.3390/ijms17050608.

Guo, H., Feng, X., Hong, C., Chen, H., Zeng, F., Zheng, B., and Jiang, D. 2017. Malate secretion from the root system is an important reason for higher resistance of Miscanthus sacchariflorus to cadmium. Physiologia Plantarum 159(3):340-353. https://doi.org/10.1111/ppl.12526.

Hall, J. L. 2002. Cellular mechanisms for heavy metal detoxification and tolerance. Journal of Experimental Botany 53(366):1-11. https://doi.org/10.1093/jexbot/53.366.1.

Igamberdiev, A. U., and Eprintsev, A. T. 2016. Organic acids: the pools of fixed carbon involved in redox regulation and energy balance in higher plants. Frontiers in Plant Science 7:1042. https://doi.org/10.3389/fpls.2016.01042.

Jones, D. L. 1998. Organic acids in the rhizosphere - a critical review. Plant and Soil 205:25-44. https://doi. org/10.1023/A:1004356007312.

Kochian, L. V., Pineros, M. A., Liu, J., and Magalhaes, J. V. 2015. Plant adaptation to acid soils: the molecular basis for crop aluminum resistance. Annual Review of Plant Biology 66:571-598. https://doi.org/10.1146/annurev-arplant-043014-114822.

Kurilenko, V. V., and Osmolovskaya, N. G. 2015. Heavy metal pollution of Kotlin Island in the Gulf of Finland. Baltica 28(1):1-10. https://doi.org/10.5200/baltica.2015.28.01.

Küpper, H., Mijovilovich, A., Meyer-Klaucke, W., and Kroneck, P. M. H. 2004. Tissue- and age-dependent differences in the complexation of cadmium and zinc in the $\mathrm{Cd} / \mathrm{Zn}$ hyperaccumulator Thlaspi caerulescens (Ganges ecotype) revealed by X-ray absorption spectroscopy. Plant Physiology 134(2):748-775. https://doi.org/10.1104/ pp.103.032953.

Li, X., Chen, X., and Cui, X. 2012. Zinc chemical forms and organic acid exudation in non-heading Chinese cabbages under zinc stress. Agricultural Sciences 3(4):562-566. https://doi.org/10.4236/as.2012.34067.

Lopez-Bucio, J., Nieto-Jacobo, M. F., Ramırez-Rodriguez, V., and Herrera-Estrella, L. 2000. Organic acid metabolism in plants: from adaptive physiology to transgenic varieties for cultivation in extreme soils. Plant Science 160(1):113. https://doi.org/10.1016/S0168-9452(00)00347-2.

Lu, L., Tian, S., Yang, X., Peng, H., and Li, T. 2013. Improved cadmium uptake and accumulation in the hyperac- cumulator Sedum alfredii: the impact of citric acid and tartaric acid. Journal of Zhejiang University-SCIENCE $B$ 14(2):106-114. https://doi.org/10.1631/jzus.B1200211.

Lux, A., Martinka, M., Vaculik, M., and White, P.J. 2011. Root responses to cadmium in the rhizosphere: a review. Journal of Experimental Botany 62(1):21-37. https://doi. org/10.1093/jxb/erq281

$\mathrm{Ma}, \mathrm{J}$. F. 2000. Role of organic acids in detoxification of aluminum in higher plants. Plant and Cell Physiol. 41(4):383390. https://doi.org/10.1093/pcp/41.4.383.

Ma, J. F., Ryan, P. R., and Delhaize, E. 2001. Aluminium tolerance in plants and the complexing role of organic acids. Trends in Plant Science 6(6):273-278. https://doi. org/10.1016/S1360-1385(01)01961-6.

Ma, J.F., Zheng, S.J., Matsumoto, H., and Hiradate, S. 1997. Detoxifying aluminium with buckwheat. Nature 390(6660):569-570. https://doi.org/10.1038/37518.

Mazen A. M. A. 2004. Calcium oxalate deposits in leaves of Corchorus olitorius as related to accumulation of toxic metals. Russian Journal of Plant Physiology 51(2):281-285. https://doi.org/10.1023/B:RUPP.0000019226.03536.21.

Mazen, A. M. A., and El Maghraby, O. M. O. 1997. Accumulation of cadmium, lead and strontium, and a role of calcium oxalate in water hyacinth tolerance. Biologia Plantarum 40(3):411-417. https://doi.org/10.1023/A:1001174132428.

Meychik, N.R., Nikolaeva, Y.I., Komarynets, O.V., and Ermakov I. P. 2011. Barrier function of the cell wall during uptake of nickel ions. Russian Journal of Plant Physiology 58(3):409-414. https://doi.org/10.1134/ S1021443711030137.

Meyer S, De Angeli, A, Fernie, A. R., and Martinoia, E. 2010. Intra- and extra-cellular excretion of carboxylates. Trends in Plant Sciences 15:40-47. https://doi.org/10.1016/j. tplants.2009.10.002.

Nigam, R., and Srivastava, M. M. 2005. Effects of carboxylic and amino acids on Cd uptake by Lycopersicum esculentum. Chemical Speciation and Bioavailability 17(1):19-26. https://doi.org/10.3184/095422905782774973.

Osmolovskaya, N. G., Kuchaeva, L. N., and Novak, V. A. 2007. Role of organic acids in the formation of the ionic composition in developing glycophyte leaves. Russian Journal of Plant Physiology 54(3):336-342. https://doi.org/10.1134/ S1021443707030077.

Panfili, F., Schneider, A., Vives, A., Perro, F., Hubert, P., Pellerin, S., and Hale, B. 2009. Cadmium uptake by durum wheat in presence of citrate. Plant and Soil 316(1-2):299309. https://doi.org/10.1007/s11104-008-9782-2.

Pellet, D. M., Grunes, D. L., and Kochian, L. V. 1995. Organicacid exudation as an aluminum-tolerance mechanism in maize (Zea mays L.). Planta 196(4):788-795. https://doi. org/stable/23383485.

Pineros, M. A., Shaff, J. E., Manslank, H. S., Alves, V. M. C., and Kochian, L. V. 2005. Aluminum resistance in maize cannot be solely explained by root organic acid exudation. A comparative physiological study. Plant Physiology 137(1):231-241. https://doi.org/10.1104/pp.104.047357.

Rauser, W. E. 1999. Structure and function of metal chelators produced by plants: the case for organic acids, amino acids, phytin, and metallothioneins. Cell Biochemistry and Biophysics 31:19-48. https://doi.org/10.1007/ BF02738153.

Ryan, P. R., Delhaize, E., and Jones, D. 2001. Function and mechanism of organic anion exudation from plant roots. Annual review of plant physiology and plant molecular biology 52:527-560. https://doi.org/10.1146/annurev. arplant.52.1.527.

Ryan, P.R., Tyerman, S.D., Sasaki, T., Yamamoto, Y., Zhang, W. H., and Delhaize E. 2011. The identification 
of aluminium-resistance genes provides opportunities for enhancing crop production on acid soils. Journal of Experimental Botany 62(1):9-20. https://doi.org/10.1146/ annurev.arplant.52.1.527.

Salt, D. E., Prince, R. C., Baker, A.J. M., Raskin, I., and Pickering, I.J. 1999. Zinc ligands in the metal hyperaccumulator Thlaspi caerulescens as determined using X-ray absorption spectroscopy. Environmental Science and Technology 33(5):713-717. https://doi.org/10.1021/es980825x.

Sarret, G., Saumitou-Laprade, P., Bert, V., Proux, O., Hazemann, J.-L., Traverse, A., Marcus, M. A., and Manceau, A. 2002. Forms of zinc accumulated in the hyperaccumulator Arabidopsis halleri. Plant Physiology 130(4):18151826. https://doi.org/10.1104/pp.007799.

Sazanova, K., Osmolovskaya, N., Schiparev S., Jakkonen K., Kuchaeva L., and Vlasov D. 2015. Organic acids induce tolerance to zinc- and copper-exposed fungi under various growth conditions. Current Microbiology 70(4):520527. https://doi.org/10.1007/s00284-014-0751-0.

Schwab, A. P., Zhu, D. S., and Banks, M. K. 2008. Influence of organic acids on the transport of heavy metals in soil. Chemosphere 72(6):986-994. https://doi.org/10.1016/j. chemosphere.2008.02.047.

Senden, M. H.M. N., Van Paassen, F.J.M., Van der Meer, A.J. G. M., and Wolterbeek, H. T. 1992. Cadmiumcitric acid-xylem cell wall interactions in tomato plants. Plant, Cell and Environment 15(1):71-79. https://doi. org/10.1111/j.1365-3040.1992.tb01459.x.

Senden M. H. M. N., van der Meer A.J. G. M., Verburg, T. G., and Wolterbeek, H. T. 1995. Citric acid in tomato plant roots and its effect on cadmium uptake and distribution. Plant and Soil 171(2): 333-339. https://doi.org/10.1007/BF00010289.

Shen, R., Iwashita, T., and Ma, J. F. 2004. Form of Al changes with Al concentration in leaves of buckwheat. Journal of Experimental Botany 55(394):131-136. https://doi. org/10.1093/jxb/erh016.

Sun, R. L., Zhou, Q. X., and Jin, C. X. 2006. Cadmium accumulation in relation to organic acids in leaves of Solanum nigrum L. as a newly found cadmium hyperaccumulator. Plant and Soil 285(1-2):125-134. https://doi.org/10.1007/ s11104-006-0064-6.

Titov, A. F., Kaznina, N. M., and Talanova, V. V. 2014. Tyazelye metally $\vee$ rastenijah. [Heavy metals in plants]. 194 pp. Karelian research center of RAS. Petrozavodsk. https:// doi.org/10.17076/eco112.

Tolrà, R. P., Poschenrieder, C., and Barceló, J. 1996. Zinc hyperaccumulation in Thlaspi caerulescens. II. Influence on organic acids. Journal of Plant Nutrition 19(12):15411550. https://doi.org/10.1080/01904169609365220.

Turgut, C., Pepe, M. K., and Cutright, T.J. 2004. The effect of EDTA and citric acid on phytoremediation of $\mathrm{Cd}, \mathrm{Cr}$, and Ni from soil using Helianthus annuus. Environmental Pollution 131(1):147-154. https://doi.org/10.1016/j.envpol.2004.01.017.

Wójcik, M., Skórzynska-Polit, E., and Tukiendorf, A. 2006. Organic acids accumulation and antioxidant enzyme activities in Thlaspi caerulescens under $\mathrm{Zn}$ and Cd stress. Plant Growth Regulation 48(2):145-155. https://doi. org/10.1007/s10725-005-5816-4.

Wu, L. H., Luo, Y. M., Xing, X. R., and Christie, P. 2004. EDTAenhanced phytoremediation of heavy metal con- taminated soil with Indian mustard and associated potential leaching risk. Agriculture, Ecosystems and Environment 102(3):307-318. https://doi.org/10.1016/j. agee.2003.09.002.

Wu, X., Li, R., Shi, J., Wang, J., Su, n Q., Zhang, H., Xing, Y., Qi, Y., Zhang, N., and Guo, Y-D. 2014. Brassica oleracea MATE encodes a citrate transporter and enhances aluminum tolerance in Arabidopsis thaliana. Plant and Cell Physiology 55(8):1426-1436. https://doi.org/10.1093/pcp/ pcu067.

Yang, J. L., Zhang, L., and Zheng, S. J. 2008. Aluminum-activated oxalate secretion does not associate with internal content among some oxalate accumulators. Journal of Integrative Plant Biology 50(9):1103-1107. https://doi. org/10.1111/j.1744-7909.2008.00687.x.

Yang, L. T., Jiang, H. X., Qi, Y.P., and Chen, L. S. 2012. Differential expression of genes involved in alternative glycolytic pathways, phosphorus scavenging and recycling in response to aluminum and phosphorus interactions in citrus roots. Molecular Biology Reports 39(5):6353-6366. https://doi.org/10.1007/s11033-012-1457-7.

Yang, L. T., Qi, Y. P., Jiang ,H. X., and Chen, L. S. 2013. Roles of organic acid anion secretion in aluminium tolerance of higher plants. BioMed Research International Volume 2013. Article ID 173682. https://doi. org/10.1155/2013/173682.

Yang, L., Zheng, S. J., He, Y. F., and Matsumoto, H. 2005. Aluminium resistance requires resistance to acid stress: a case study with spinach that exudes oxalate rapidly when exposed to Al stress. Journal of Experimental Botany 56(414):1197-1203. https://doi.org/10.1093/jxb/eri113.

Yang, X. E., Baligar, V. C., Foster, J. C., and Marten, D. C. 1997. Accumulation and transport of nickel in relation to organic acid in ryegrass and maize grown with different nickel levels. Plant and Soil 196(2):271-276. https://doi. org/10.1023/A:1004270528532.

Yang, X., Feng, Y., He, X. L., and Stoffella, P.J. 2005. Molecular mechanisms of heavy metal hyperaccumulation and phytoremediation. Journal of Trace Elements in Medicine and Biology 18(4):339-353. https://doi.org/10.1016/j. jtemb.2005.02.007.

Yang, X. E., Li, T. Q., Yang, J. C., He, Z. L., Lu, L. L., and Meng, F. H. 2006. Zinc compartmentation in root, transport into $x y-$ lem, and absorption into leaf cells in the hyperaccumulating species of Sedum alfredii Hance. Planta 224(1):185195. https://doi.org/10.1007/s00425-005-0194-8.

Yang, Y. Y., Jung, J. Y., Song, W. Y., Suh, H. S., and Lee, Y. 2000. Identification of rice varieties with high tolerance or sensitivity to lead and characterization of the mechanism of tolerance. Plant Physiology 124(3):1019-1026. https:// doi.org/10.1104/pp.124.3.1019.

Zhao, F.J., Lombi, E., Breedon, T., and McGrath, S. P. 2000. Zinc hyperaccumulation and cellular distribution in Arabidopsis halleri. Plant, Cell and Environment 23(5):507514. https://doi.org/10.1046/j.1365-3040.2000.00569.x.

Zhu, X. F, Zheng, C., Hu, Y.T., Jiang, T., Liu, Y., Dong, N. Y., Yang J. L, and Zheng, S. J. 2011. Cadmium-induced oxalate secretion from root apex is associated with cadmium exclusion and resistance in Lycopersicon esulentum. Plant, Cell and Environment 34(7):1055-1064. https://doi. org/10.1111/j.1365-3040.2011.02304.x. 